\title{
THE GENESIS OF LOCAL SELF-GOVERNMENT IN UKRAINE. URGENT ISSUES OF LEGAL SUPPORT OF LOCAL SELF-GOVERNMENT
}

\section{Panchyshyn R. I.}

\section{INTRODUCTION}

The reform of local self-government is ongoing today in Ukraine, its tasks in accordance with the Concept of the Reform of Local SelfGovernment and Territorial Organization of Power in Ukraine approved by the Order of the Cabinet of Ministers of Ukraine dated April 01, 2014 No. $333^{1}$, are to form effective local self-government and territorial organization of power, to create and support an adequate living environment for citizens, to provide high-quality and accessible public services, to establish institutions of direct democracy, etc.

To achieve those objectives, in particular, proper legislative support for the process of reforming local self-government and formation of necessary organizational conditions are of particular importance. Significant steps aimed at achieving the goal of legislative support for the process of reforming local self-government have been implemented, in particular, the Law of Ukraine "On Voluntary Association of Territorial Communities"2 is adopted, amendments and additions to a number of legislative acts, etc. are made. Meanwhile, the process of formalization of constitutional and legal regulation of the process of implementation of local self-government reform in Ukraine is ongoing.

In order to determine the further prospects for development of legislation in this field, it is necessary to conduct a study of the current state of legal support of local self-government reform in Ukraine, to reveal the shortcomings and gaps of the relevant legislation and to develop proposals for further improvement of legislation in this field.

${ }^{1}$ On Approval of the Concept of the Reform of Local Self-Government and Territorial Organization of Power in Ukraine. Order of the Cabinet of Ministers of Ukraine dated April 01, 2014 No. 333-r. [Electronic resource]. - Access mode: http://zakon3.rada.gov.ua/laws/show/ 333-2014-\%D1\%80. (in Ukrainian)

${ }^{2}$ On Voluntary Association of Territorial Communities. The Law of Ukraine dated February 05, 2015 No. 157-VIII. [Electronic resource]. - Access mode: http://zakon3.rada.gov.ua/laws/ show/157-19. (in Ukrainian) 


\section{The importance of the European legal acts in the field of regulation of the local self-government for successful implementation of the constitutional reform in Ukraine}

At the current stage of realization of the local self-government reform in Ukraine, European law is of particular relevance.

Thus, one of the first international instruments in the European transnational space has become the European Outline Convention on Transfrontier Co-operation between Territorial Communities or Authorities $^{3}$. This Convention imposes on the contracting parties the obligation to maintain and promote cross-border co-operation between territorial communities and authority under the jurisdiction of which the concerned community is and the territorial communities or authorities being under the jurisdiction of the other contracting parties.

The main purpose of the European Outline Convention on Transfrontier Cooperation between Territorial Communities or Authorities is, with due regard to the respective constitutional provisions of each party, to facilitate the conclusion of agreements and coming to understanding possibly needed for it.

Another international act is the European Urban Charter which holds the contracting parties responsible for building a system of governance that takes account of the new demands of democracy, in particular of its dimension of city people and urban territory residents participation in addressing and making decisions on issues of local value ${ }^{4}$.

The European Urban Charter is aimed, first and foremost, at creating conditions for equal development of urban territorial communities, eliminating social stratification within such communities etc.

The Framework Convention for Protection of National Minorities is equally important for regulation of the status of territorial community at international level. In particular, the content of the provisions of this Convention implies that the contracting parties undertake to guarantee to persons belonging to national minorities the right of equality under the law and the right to equal protection by the law. In this regard, any discrimination based on belonging to a national minority is prohibited ${ }^{5}$.

${ }^{3}$ European Outline Convention on Transfrontier Cooperation between Territorial Communities or Authorities. International Document dated May 21, 1980. [Electronic resource]. - Access mode: http://zakon3.rada.gov.ua/laws/show/995_106.

${ }^{4}$ European Urban Charter. International Document, 1992. [Electronic resource]. - Access mode: http://www.slg-coe.org.ua/wp-content/uploads/2015/05/Principle-9.-European-chart.pdf.

${ }^{5}$ Framework Convention for the Protection of National Minorities. International Document dated February 01, 1995. [Electronic resource]. - Access mode: http://zakon2.rada.gov.ua/ laws/show/995_055. 
One of the fundamental international legal acts in the field of determining the status of a territorial community (united territorial community) is the European Charter of Local Self-Government which at the international level has confirmed the status of a territorial community, with fixation of its right to implement local self-government, and has determined the basic principles for formation of elected local selfgovernment bodies and fulfillment of their functions by those.

While exploring the importance of the European Charter of Local SelfGovernment $^{6}$ for the formation and development of a territorial community (united territorial community) in Ukraine, it is worth noting that in the European Community this document has played a decisive role in promoting the democratic foundations of realization of local selfgovernment.

In particular, foreign scientists note that the following axiological principles have been embodied in the European Charter of Local SelfGovernment: the local authorities are one of the main pillars of any democratic regime; presence of local authorities with real responsibilities ensures more effective realization of public government, public authorities are brought closer to citizens; safeguarding and strengthening of local self-government in different European countries is an important contribution to building a democratic Europe with dominating principles of democracy and decentralization of power; existence of local authority is recognized, its democratic embodiment are the elected representative decision-making bodies having a high degree of autonomy as to their responsibilities, the ways and means by which the responsibilities are fulfilled, and provided with the resources necessary to fulfill those responsibilities ${ }^{7}$.

Ukraine has ratified the European Charter of Local Self-Government in $1997^{8}$, without any provisions and reservations, thus having become a full member of this international instrument.

In 2009, the Additional Protocol to the European Charter of Local SelfGovernment on the Right to Participate in the Affairs of a Local Self-

${ }^{6}$ European Charter of Local Self-Government. International Document dated October 15, 1985. [Electronic resource]. - Access mode: http://zakon5.rada.gov.ua/laws/show/994_036.

${ }^{7}$ Himsworth C. Treaty-Making For Standards Of Local Government: The European Charter of Local Self-Government and its Possible Application Beyond Europe / University of Edinburgh School of Law Working. 2011. № 2011/24. 17 p. P. 4.

${ }^{8}$ On Ratification of the European Charter of Local Self-Government. Law of Ukraine dated July 15, 1997 No. 452/97-VR. [Electronic resource]. - Access mode: http://zakon3.rada.gov.ua/ laws/show/452/97-\%D0\%B2\%D1\%80. (in Ukrainian). 
Government Authority was adopted ${ }^{9}$, this was ratified by Ukraine as late as $2014^{10}$. The Additional Protocol obliges the participants of the European Charter of Local Self-Government to ensure that national legislation has to make provisions for means promoting realization of the rights of local self-government bodies.

In this context, it is likely that such means as the right of voters to recall an elected local self-government person, or to early terminate his/her authorities.

Considering the fundamental importance of the European Charter of Local Self-Government for the development of local democracy in European countries, the Council of Europe periodically monitors the implementation of the Charter norms in the national legislation of the contracting States and provides recommendations on the further implementation of the relevant provisions of the Charter.

In such a way, on the basis of monitoring of the European countries adherence to the European Charter of Local Self-Government, it is pointed out that the adoption of the Charter and its ratification in many countries have led to reformation of local self-government accompanied by updating legislation in the sphere of local democracy. For some countries, the Charter and its principles have served as the basis for building a new system of local self-government. Along with that, the results of monitoring show that local self-government in many Member States remains unstable, in particular due to a lack of efficient legislative framework and slow reformation of administrative practice ${ }^{11}$.

Thus, most European countries have encountered some difficulties in implementing the principles of the European Charter of Local SelfGovernment, in particular with regard to reforming their own local selfgovernment system and bringing national legislation in line with European standards. Therefore, it is not surprising that similar problems are also present in our State in the process of implementing the reform for decentralization of power.

${ }^{9}$ Additional Protocol to the European Charter of Local Self-Government on the Right to Participate in the Affairs of a Local Self-Government Authority. International Document dated November 16, 2009. [Electronic resource]. - Access mode: http://zakon5.rada.gov.ua/laws/show/ 994_b49/paran2\#n2.

${ }^{10}$ On Ratification of the Additional Protocol to the European Charter of Local SelfGovernment on the Right to Participate in the Affairs of a Local Self-Government Authority. The Law of Ukraine dated September 02, 2014 No. 1664-VII. [Electronic resource]. - Access mode: http://zakon5.rada.gov.ua/laws/show/1664-18. (in Ukrainian)

${ }^{11}$ Kirchmair L. International Law and Public Administration: The European Charter of Local Self-Government / European treaty series. 2015. No. 122. P. 124-135. 
In order to facilitate the further implementation of local selfgovernment reform and to ensure the implementation of the European standards of local democracy, the Parliamentary Assembly of the Council of Europe is developing recommendations, in particular, in 2005, the Resolution No. 1466 (2005) "On Fulfillment of Duties and Obligations by Ukraine" is adopted, with one of the clauses pointing on continuation of the reform of local self-government to implement the provisions of the European Charter of Local Self-Government ${ }^{12}$.

Another important document was adopted by the Council of Europe in 2005 - the Recommendation No. R (2005) to Member States on the practice of border and inter-territorial cooperation of territorial communities ${ }^{13}$.

\section{The current state of legal regulation of the process of reforming local self-government in Ukraine}

The fundamental European principles of local democracy have been embodied in the constitutional legislation of Ukraine.

Thus, the Constitution of Ukraine enshrines the right of the territorial community to realize local self-administration; the principles of formation and types of representative bodies of local self-government are determined; the principles of interaction between the local self-government bodies and public authorities, including local executive bodies, etc. In addition, at the level of the Constitution of Ukraine, the guaranteed right of the territorial community to independently manage communal property resources ${ }^{14}$ is fixed.

In characterizing the constitutional foundations of ensuring the process of implementation of the local self-government reform it should be noted that in most European countries local self-administration is guaranteed at the constitutional level.

Some scientists at comparing the constitutions of the most countries in the world point out that the basic provisions enshrined in those relate to the functioning of local self-government, namely: the basic principles of the

${ }^{12}$ On Fulfillment of Duties and Obligations by Ukraine. Resolution 1466 (2005) of the Parliamentary Assembly of the Council of Europe dated October 5, 2005. [Electronic resource]. Access mode: http://zakon3.rada.gov.ua/laws/show/994_611.

${ }^{13}$ On Good Practices in and Reducing Obstacles to Transfrontier and Interterritorial Cooperation between Territorial Communities or Authorities. Recommendation No. R (2005) 2 of the Committee of Ministers of the Council of Europe to Member States dated January 19, 2005. [Electronic resource]. - Access mode: http://zakon3.rada.gov.ua/laws/show/994_667.

${ }^{14}$ Constitution of Ukraine. The Law of Ukraine of 28.06.1996 No. 254k/96-VR. [Electronic resource]. - Access mode: http://zakon3.rada.gov.ua/laws/show/254\%D0\%BA/96-\%D0\%B2\% D1\%80. (in Ukrainian) 
organization of local self-government; principles of administrative-territorial division; organizational forms of realization of local self-administration, fundamentals of its competence, internal structure; the role and the place of local authorities in the political system of society; administrative supervision; guarantees for the local self-government (constitutional, judicial, legislative, financial etc. $)^{15}$.

The constitutional principles of the local self-government are specified and detailed in a number of laws and by-laws.

So, the legal basis for the status of a united territorial community is provided by the laws of Ukraine "On Local Self-Government in Ukraine" ${ }^{16}$, "On Service in Local Self-Government Bodies"17, "On Public SelfOrganization Bodies”"18, “On Cooperation of Territorial Communities”, "On Voluntary Association of Territorial Communities", "On Principles of State Regional Policy”" "On Local Elections”,21, and so forth.

First of all, it should be emphasized that the legislation of Ukraine in the field under investigation has been substantially updated in connection with the implementation of the decentralization of power reform by adopting new or making amendments to existing laws.

So, in 2015, the Law of Ukraine "On Principles of State Regional Policy" was adopted, this defined the basic principles of formation and implementation of the State regional policy. The State regional policy in this Law is defined as a system of goals, measures, means and coordinated actions of central and local executive bodies, local selfgovernment bodies and officials of those to ensure high quality of life of people through the whole territory of Ukraine, with account of natural,

${ }^{15}$ Petryshyna M.O., Petryshyn O.O. International legal standards in the field of local selfgovernment. Kh.: Pravo, 2016. 44 p. P. 18. (in Ukrainian)

${ }^{16}$ On Local Self-Government in Ukraine. The Law of Ukraine dated May 21, 1997 No. 280/97. [Electronic resource]. - Access mode: http://zakon3.rada.gov.ua/laws/show/280/97\%D0\%B2\%D1\%80. (in Ukrainian)

${ }^{17}$ On Service in Local Self-Government Bodies. The Law of Ukraine dated June 07, 2001 No. 2493-III. [Electronic resource]. - Access mode: http://zakon5.rada.gov.ua/laws/show/249314. (in Ukrainian)

${ }^{18}$ On Public Self-Organization Bodies. The Law of Ukraine dated July 11, 2001 No. 2625-III. [Electronic resource]. - Access mode: http://zakon2.rada.gov.ua/laws/show/2625-14. (in Ukrainian)

${ }^{19}$ On Cooperation of Territorial Communities. The Law of Ukraine dated June 17, 2014 No. 1508-VII. [Electronic resource]. - Access mode: http://zakon3.rada.gov.ua/laws/show/ 1508-18. (in Ukrainian)

${ }^{20}$ On the Principles of State Regional Policy. The Law of Ukraine dated February 05, 2015 No. 156-VIII. [Electronic resource]. - Access mode: http://zakon3.rada.gov.ua/laws/show/156-19. (in Ukrainian)

${ }^{21}$ On Local Elections. The Law of Ukraine dated July 14, 2015 No. 595-VIII. [Electronic resource]. - Access mode: http://zakon5.rada.gov.ua/laws/show/595-19. (in Ukrainian) 
historical, environmental, economic, geographical, demographic and other peculiarities of the regions, their ethnic and cultural identity ${ }^{20}$.

Adoption of this law is of large regulatory and strategic importance for harmonization of the legal relationships that are formed in the field of formation and implementation of regional policy, in particular, this Law identifies the sources of funding for the measures aimed at the implementation of the regional policy, the entities responsible for this direction of the State policy, monitoring of the state of implementation of regional policy is introduced.

The key laws that have determined the status of a united territorial community in Ukraine are the laws "On Local Self-Government in Ukraine”, "On Voluntary Association of Territorial Communities", "On Local Elections".

So, the Law of Ukraine "On Local Self-Government in Ukraine"16 has been adopted as far back as 1997, however, since then it has been amended and supplemented, with amendments mainly aimed at empowering the territorial community and its representative bodies. In particular, the powers of local self-government bodies are supplemented by the ones as the right to: reorganization or liquidation of educational establishments of communal ownership that is carried out by decision of the local council ${ }^{22}$, formation and maintenance of the register of territorial community in accordance with the law ${ }^{23}$, exercising the powers in the area of use of urban passenger transport ${ }^{24}$, etc.

In Art. 6 of the Law of Ukraine "On Local Self-Government in Ukraine» ${ }^{\text {, }}$, the guaranteed right of territorial communities to voluntarily unite in one rural, settlement, urban territorial community, to form joint bodies of local self-government and to elect respectively a village, settlement, city head is captured. The law also gives the territorial community the right to leave the association.

The procedure for association of a territorial community and for withdrawal from the association is determined by the Law of Ukraine "On Voluntary Association of Territorial Communities", This Law also

${ }^{22}$ On Amendments and Declaring Lapsed Some Legislative Acts of Ukraine. The Law of Ukraine dated December 28, 2014 No. 76-VIII. [Electronic resource]. - Access mode: http://zakon2.rada.gov.ua/laws/show/76-19/paran130\#n130. (in Ukrainian)

${ }^{23}$ On Amendments to Some Legislative Acts of Ukraine on Extending the Authorities of Local Self-Government Bodies and Optimizing the Provision of Administrative Services. The Law of Ukraine dated December 10, 2015 No. 888-VIII. [Electronic resource]. - Access mode: http://zakon2.rada.gov.ua/laws/show/888-19/paran44\#n44. (in Ukrainian)

${ }^{24}$ On Amendments to Some Legislative Acts of Ukraine on the Implementation of the Automated System of Accounting for Fare Payment in Urban Passenger Transport. The Law of Ukraine dated January 17, 2017 No. 1812- 
regulates the principles, terms for association of territorial community; determines the directions and means of State support of a viable united territorial community, etc.

Formation of joint bodies of local self-government by a united territorial community is carried out in accordance with the procedure prescribed by the Law of Ukraine "On Local Elections"21.

The electoral legislation, in particular the one regulating the procedure for organizing and holding elections in the united territorial communities, is represented by numerous normative and legal acts the adoption of which has been often accompanied by inconsistency caused by lack of a unified conceptual vision by the legislator of how the process of holding elections in united territorial communities should be organized.

Thus, of large importance for forming a new local self-government system is the Law of Ukraine "On Local Elections",21, with enactment of which the Law of Ukraine "On election of deputies of the Verkhovna Rada of the Autonomous Republic of Crimea, local councils and village, settlement, city mayors" ${ }^{25}$ has become void. The new Law has introduced some significant innovations, in particular regarding the differentiation of the way of organizing and holding elections depending on the size of population of the respective territorial (united territorial) community, as well as the requirements for lists of political parties, etc.

Along with that, some scientists soundly point out that introduction into the practice of formation of local self-government bodies in Ukraine of a proportional electoral system does not completely meet the needs of territorial communities - residents of villages, towns and cities. Their interests will not always be properly represented and protected in district and regional councils. While the importance of local elections is determined, first of all, by identification of social, economic and other problems, interests, needs of citizens in a certain administrative-territorial unit and by development of preconditions to resolve those by the local self-government bodies ${ }^{26}$.

\footnotetext{
${ }^{25}$ On election of deputies of the Verkhovna Rada of the Autonomous Republic of Crimea, local councils and village, settlement, city mayors. The Law of Ukraine dated July 10, 2010 No 2487-VI. [Electronic resource]. - Access mode: http://zakon3.rada.gov.ua/laws/show/2487-17. (in Ukrainian)

${ }^{26}$ Martseliak O.V. Electoral system in Ukraine: search for the optimal model // Bulletin of the Kharkiv National University of Internal Affairs. - 2007. - No. 37. - P. 83-84. (in Ukrainian)
} 


\section{Some problems of legal regulation of the process of reforming local self-government and ways for resolving those}

At determining the state of constitutional and legal support for the implementation of local self-government reform it should be noted that the process of forming united territorial communities and reorganization of local self-government bodies is the subject of numerous scientific discussions today.

So, V.V. Tolkovanov soundly points out that the reform of local selfgovernment is impossible without qualitative changes in the legal field, modernization of current legislation in force. The scientist believes that as a matter of priority Constitution of Ukraine should be amended, in particular in regard to formation of executive bodies of regional and district councils and to division of powers between those; new version of laws on local self-government, service in local self-government bodies, on local State administrations is developed and adopted, other legislative and regulatory legal acts on introduction of the mechanism of direct people power, improvement of legal regulation of procedures of holding general meetings of citizens at their place of residence and establishment of additional guarantees for activity of public self-organization bodies etc ${ }^{27}$..

L.A. Belukha believes that in order to increase the effectiveness of local self-government reform it is necessary to ensure: reviewing and formulating a prospective schedule for integration of territorial communities with maximum account of geographical, cultural, ethnic and other specificities of communities; information and clarification support for the process of integration of territorial communities; conducting training seminars for local self-government officials and the public on various aspects of the reform ${ }^{28}$.

Electoral law has a significant impact on the process of reforming local self-government in Ukraine, since its shortcomings substantially affect the process of calling and holding the first elections in the united territorial communities.

In particular, the lack of political will of the Central Election Commission, the untimely receipt of requests from State administrations and proper methodological support of territorial election commissions by the

\footnotetext{
${ }^{27}$ Tolkovanov V.V. Priorities and approaches to modernization of local self-government at the present stage: domestic and foreign experience // The theory and practice of public administration and local self-government. - 2017. - No. 1. - P. 6 - 7. [Electronic resource]. Access mode: http://el-zbirn-du.at.ua/2017_1/28.pdf. (in Ukrainian)

${ }^{28}$ Belukha L.A. The concept of territorial community and capable territorial community / Theory and practice of public administration. - 2017. - No. 1(56). - P. 5. [Electronic resource]. Access mode: http://www.kbuapa.kharkov.ua/e-book/tpdu/2017-1/doc/3/02.pdf. (in Ukrainian)
} 
central one are a major problem in calling and holding elections in united territorial communities.

According to Part 8 of Art. 7 of the Law of Ukraine "On Voluntary Association of Territorial Communities", the first elections of deputies of rural, settlement, city councils of united territorial communities and respective rural, settlement, city heads are scheduled by the Central Election Commission at respective appeals of the Council of Ministers of the Autonomous Republic of Crimea, regional State administrations on calling the first local elections in accordance with the procedure prescribed by law ${ }^{2}$.

At that, in some united communities a situation of untimely receipt of requests for the first local elections from regional State administrations has taken place. For example, in 2016 such requests on elections were not received in 300 united territorial communities, and as a result the Central Election Commission did not call the elections in such communities.

Along with that, as it isindicated in the official response of the Ministry of Regional Development, Construction and Housing and Communal Services of Ukraine to the Central Election Commission, absence of decisions of the Commission on calling the first elections in the united territorial communities, in particular the ones formed around the cities of regional significance, adversely affects the further initiation of association and, accordingly, use of the State budget funds for holding the first local elections there ${ }^{29}$. The Ministry's report also states that the Central Election Commission, without any reason, has independently determined that it schedules the elections in the communities only twice a year - in April and October, and, as an exception, in December as well ${ }^{30}$ (P. 2).

At that, the Resolution of the Central Election Commission "On Procedure for calling the First Elections of Deputies of Rural, Settlement, City Councils of United Territorial Communities and the respective Rural, Settlement, City Mayors” defines an exhaustive list of grounds on which the commission may decide to refuse holding such elections.

In addition to the problematic aspects discussed above, the issues of establishing boundaries of electoral constituencies in accordance with the requirements of current legislation remain unresolved. So, the Committee of Voters of Ukraine on this issue has noted that under current conditions

\footnotetext{
${ }^{29}$ Stop the practice of finding reasons and take legal opportunities - Minregion to the CEC: Decentralization. - 2017. - [Electronic resource]. - Access mode: http://decentralization.gov.ua/ news/7380. (in Ukrainian)

${ }^{30}$ First Elections in United Communities. An Analytical Report. Committee of Voters of Ukraine. Kyiv. - 2017. - 45 p. - P. 2. (in Ukrainian)
} 
it is practically impossible to ensure simultaneous keeping to the norms of the Law of Ukraine "On Local Elections" regarding compliance with administrative boundaries and equality of voters in districts because of the electoral systems used at the local elections and the imperfection of administrative-territorial structure of Ukraine $^{30}$ (P. 2).

The problematic issues discussed above that arise at organizing and holding elections in a united territorial community are mainly caused by imperfection of national legislation in this area.

Following the first local elections in 2015 in the United Territorial Communities it was found out that the current legislation had a number of gaps and shortcomings that in practice give rise to particular problems. Therefore, in order to close those gaps, the Verkhovna Rada of Ukraine within the period of the years 2016-2018 has developed and adopted some draft laws amending the electoral legislation of Ukraine.

According to some scientists, adoption by the Verkhovna Rada of Ukraine of draft laws with register numbers No. 4772 and No. 5520 (laws currently in force) was of particular importance for implementation of the decentralization reform, and this significantly influenced the tactics of reforming the administrative and territorial system as a component of the reform of local self-government and territorial organization of power ${ }^{31}$.

So, the Law of Ukraine "On Amendments to Some Legislative Acts of Ukraine (on voluntary association of territorial communities)" (the draft law had the register number No. 4772) ${ }^{32}$, was adopted on February 9, 2017 and signed by the President of Ukraine on March 17, 2017.

This law introduces amendment and additions to the laws of Ukraine “On Voluntary Association of Territorial Communities" and "On Local Elections" in the part related to the accession of territorial communities to an already united community. In particular, due to adoption of this Law the problem of ensuring the participation of the members of the affiliated territorial community in formation of representative bodies of local selfgovernment has been partially resolved by introducing additional elections in the united territorial communities.

It is stipulated that the by-elections are to be called not later than in 70 days before the day of elections, and the election process shall be started in 50 days before the day of the by-elections. The total composition of the

${ }^{31}$ Decentralization - 2017. The reform will go on. - 2017. - [Electronic resource]. - Access mode: https://sorada.gov.ua/actual/18489-detsentralizatsija-2017-reforma-bude-prodovzhuvatys.html. (in Ukrainian)

${ }^{32}$ On Amendments to Some Legislative Acts of Ukraine (on Voluntary Association of Territorial Communities). The Law of Ukraine dated June 03, 2016. No. 4772. [Electronic resource]. - Access mode: http://w1.c1.rada.gov.ua/pls/zweb2/webproc4_1?pf3511=59314. (in Ukrainian) 
local council is at that increased beyond the determined by the part three of this article due to holding additional elections to the village, settlement, city council additionally by the number of newly formed single-mandate constituencies that is defined as the ratio of voters of territorial communities that have joined, to the number of voters of territorial community they have joined to, multiplied by the general composition of the council determined by the part three of this article, though not less than the number of territorial communities that have joined up ${ }^{33}$.

Along with that, the draft law does not solve the problem of ensuring the participation of members of the territorial community that has joined up in formation in the united territorial community of the chief, of village, settlement, city mayor, if they have already been elected, and accordingly the procedure for termination of powers of the heads of the territorial community that has decided to join.

The Law of Ukraine "On Amendments to Some Legislative Acts of Ukraine on the Features of Voluntary Association of Territorial Communities Located in the Territories of Adjacent Areas ${ }^{33}$, was adopted on March 14, 2017 and returned with the signature of the President of Ukraine on April 3, 2017. This Law is aimed at partially solving the problem of determining the boundaries of constituencies at organizing and holding the first elections in a united territorial community.

The most debatable is the Law of Ukraine "On Amendments to the Law of Ukraine "On Voluntary Association of Territorial Communities" as to voluntary accession of territorial communities of villages, settlements to territorial communities of cities of regional significance"34 adopted on April 3, 2018 and signed by the President of Ukraine on May 4, 2018. In accordance with this Law, it is proposed to declare as viable united territorial communities for the cases provided for in the Articles $8^{1}-8^{3}$ of the Law the territorial communities of cities Republic significance of the Autonomous Republic of Crimea, of regional significance. In other words, the drafters of the Law propose to automatically equate the territorial

\footnotetext{
${ }^{33}$ On Amendments to Some Legislative Acts of Ukraine on the Features of Voluntary Association of Territorial Communities Located in the Territories of Adjacent Areas. The Law of Ukraine dated December 09, 2016 No. 5520. [Electronic resource]. - Access mode: http://w1.c1.rada.gov.ua/pls/zweb2/webproc4_1?pf3511=60681. (in Ukrainian)

${ }^{34}$ On Amendments to the Law of Ukraine "On Voluntary Association of Territorial Communities" on the voluntary accession of territorial communities of villages, settlements to territorial communities of cities of regional significance. The Law of Ukraine dated April 03, 2018 No. 2379-VIII. [Electronic resource]. - Access mode: http://w1.c1.rada.gov.ua/pls/zweb2/ webproc4_1?pf3511=61814. (in Ukrainian)
} 
communities of the cities of regional and republican significance to viable united territorial communities.

Along with that, the Opinion of the Scientific and Expert Administration Head Office to the draft of this Law clearly indicates its inconsistency with the basic constitutional principles of territorial organization and local selfgovernment, that is, in fact, it focused on the unconstitutionality of the provisions of this $\mathrm{Law}^{35}$.

It should be noted that the provisions of the Law of Ukraine "On Amendments to the Law of Ukraine "On Voluntary Association of Territorial Communities" as to voluntary accession of territorial communities of villages, settlements to territorial communities of cities of regional significance" make evidence of the following:

1) since one of the principles of association of territorial communities is the principle of voluntariness, adoption of this Law leads to violation of this principle. In support of this conclusion, it should be noted that the territorial communities of cities of regional and republican significance, are usually large and respectively vitally capable and do not need to go into association, therefore, the way chosen in this Law to "encourage" such communities to association with small villages and settlements will violate the principle of voluntariness;

2) the mechanism of association of territorial communities introduced in the Law is such that it does not meet the constitutional norms, since the system of united territorial communities and their bodies is to be built according to the system of administrative and territorial organization that should include the villages (several villages), settlements, cities, districts and regions that are to be administrated by the respective local selfgovernment bodies and the local executive authorities;

3) the legislator has empowered the Cabinet of Ministers of Ukraine to act on behalf of the State in the process of declaring the united territorial communities viable and to make respective administrative decisions on the normative fixation of such declaration in the form of a by-law, though in the Law under consideration such powers are transferred to the Verkhovna Rada of Ukraine, and this is in contradiction with the constitutional principle of distribution of powers.

\footnotetext{
${ }^{35}$ Opinion of the Head Scientific and Expert Office on the Draft Law «On Amendments to the Law of Ukraine "On Voluntary Association of Territorial Communities" on the voluntary accession of territorial communities of villages, settlements to territorial communities of cities of regional significance» dated June 06, 2017. [Electronic resource]. - Access mode: http://w1.c1.rada.gov.ua/ pls/zweb2/webproc4_1?pf3511=61814. (in Ukrainian)
} 
Therefore, the Law of Ukraine "On Amendments to the Law of Ukraine "On Voluntary Association of Territorial Communities" as to voluntary accession of territorial communities of villages, settlements to territorial communities of cities of regional significance" is to be be declared unconstitutional on the grounds stated above.

In view of the aforementioned, an appeal is directed to the Constitutional Court of Ukraine under Articles 8 and 55 of the Constitution of Ukraine regarding the unconstitutionality of the Draft Law on Amendments to the Law of Ukraine "On Voluntary Association of Territorial Communities" as to voluntary accession of territorial communities of villages, settlements to territorial communities of cities of regional significance” as of May 18, 2017 under input number No. 6466, adopted and approved on April 03, 2018 in violation of the Law of Ukraine "On voluntary association of territorial communities", Articles 24, 71, 141 of the Constitution of Ukraine, the Law of Ukraine "On Local Elections", the requirements of the Art. 90 of the Law of Ukraine "On Regulations of the Verkhovna Rada of Ukraine”.

\section{CONCLUSIONS}

Thus, as a result of the study, we can draw the following conclusions.

1. The last phase of the reform of local self-government has begun within the framework of the constitutional reform of decentralization of power in 2015 and is still ongoing. The procedure for association of territorial community and for formation of local self-government bodies of the united territorial community is finally settled during this period. Thus, the State, in an effort to strengthen the financial and institutional viability of territorial community, has significantly expanded the powers of the united territorial communities at the local level. However, for the final legislative formulation of the results of the reform it is necessary to make respective amendments to the Constitution of Ukraine, to develop specific institutional and organizational measures.

2. The actual problems of implementation of the local self-government reform are: 1) some procedures and stages of implementation of the reform (the procedure for holding local referendums, clear timing of scheduling the first, intermediate local elections, etc.) are not regulated; 2) lack of proper organizational conditions for further implementation of the reform (no register of agreements on cooperation of territorial communities is created); 3) the disproportionality of the allocated funds and the financial burden laid upon the territorial communities to maintain territories, and so on.

2. In order to further improve the legislation in the field of regulation of association of territorial communities it is necessary: 1) to enshrine in the 
Laws of Ukraine "On Voluntary Association of Territorial Communities" and "On local elections" that in a territorial community having joined an associated community the powers of the chief and, accordingly, the village, settlement, city mayor shall be terminated from the instant of holding additional elections in such a community to the respective local council and the beginning of the powers of its newly elected members; 2) To declare unconstitutional the Law of Ukraine "On Amendments to the Law of Ukraine "On Voluntary Association of Territorial Communities" as to voluntary accession of territorial communities of villages, settlements to territorial communities of cities of regional significance"; 3) to adopt the Law of Ukraine "On Local Initiatives" that is to make it possible to unify the procedure of submission of proposals for association by the members of territorial community under the procedure of local initiative.

\section{SUMMARY}

The monograph analyzes the current state of legal regulation of implementation of the local self-government reform. The author reviews the European legislation and sets out its importance for the implementation of the local self-government reform in Ukraine. Particular attention is given to the study of electoral law. In the context of the problem of the ordering and holding the first and additional elections in the united territorial communities, as a prerequisite for successful implementation of the local self-government reform, proposals for improvement of the law on local elections are developed. On the basis of the analysis of constitutional legislation in this field carried out, a number of gaps and shortcomings were identified. In particular, it is concluded that some legislative acts that fix the recognition of the capacity of some territorial communities are unconstitutional. Proposals for further development of legislation in the field of regulation of implementation of the local self-government reform in Ukraine are substantiated.

\section{REFERENCES}

1. On Approval of the Concept of the Reform of Local SelfGovernment and Territorial Organization of Power in Ukraine. Order of the Cabinet of Ministers of Ukraine dated April 01, 2014 No. 333-r. [Electronic resource]. - Access mode: http://zakon3.rada.gov.ua/laws/ show/333-2014-\%D1\%80. (in Ukrainian)

2. On Voluntary Association of Territorial Communities. The Law of Ukraine dated February 05, 2015 No. 157-VIII. [Electronic resource]. Access mode: http://zakon3.rada.gov.ua/laws/show/157-19. (in Ukrainian) 
3. European Outline Convention on Transfrontier Cooperation between Territorial Communities or Authorities. International Document dated May 21, 1980. [Electronic resource]. - Access mode: http://zakon3.rada.gov.ua/laws/show/995_106.

4. European Urban Charter. International Document, 1992. [Electronic resource]. - Access mode: http://www.slg-coe.org.ua/wp-content/uploads/ 2015/05/Principle-9.-European-chart.pdf.

5. Framework Convention for the Protection of National Minorities. International Document dated February 01, 1995. [Electronic resource]. Access mode: http://zakon2.rada.gov.ua/laws/show/995_055.

6. European Charter of Local Self-Government. International Document dated October 15, 1985. [Electronic resource]. - Access mode: http://zakon5.rada.gov.ua/laws/show/994_036.

7. Himsworth C. Treaty-Making For Standards Of Local Government: The European Charter of Local Self-Government and its Possible Application Beyond Europe / University of Edinburgh School of Law Working. 2011. № 2011/24. 17 p.

8. On the Ratification of the European Charter of Local SelfGovernment. Law of Ukraine dated July 15, 1997 No. 452/97-VR. [Electronic resource]. - Access mode: http://zakon3.rada.gov.ua/laws/ show/452/97-\%D0\%B2\%D1\%80. (in Ukrainian)

9. Additional Protocol to the European Charter of Local SelfGovernment on the Right to Participate in the Affairs of a Local SelfGovernment Authority. International Document dated November 16, 2009. [Electronic resource]. - Access mode: http://zakon5.rada.gov.ua/laws/ show/994_b49/paran2\#n2.

10. On Ratification of the Additional Protocol to the European Charter of Local Self-Government on the Right to Participate in the Affairs of a Local Self-Government Authority. The Law of Ukraine dated September 02, 2014 No. 1664-VII. [Electronic resource]. - Access mode: http://zakon5.rada.gov.ua/laws/show/1664-18. (in Ukrainian)

11. Kirchmair L. International Law and Public Administration: The European Charter of Local Self-Government / European treaty series. 2015. No. 122. P. 124-135.

12. On Fulfillment of Duties and Obligations by Ukraine. Resolution 1466 (2005) of the Parliamentary Assembly of the Council of Europe dated October 5, 2005. [Electronic resource]. - Access mode: http://zakon3.rada.gov.ua/laws/show/994_611.

13. On Good Practices in and Reducing Obstacles to Transfrontier and Interterritorial Cooperation between Territorial Communities or 
Authorities. Recommendation No. R (2005) 2 of the Committee of Ministers of the Council of Europe to Member States dated January 19, 2005. [Electronic resource]. - Access mode: http://zakon3.rada.gov.ua/ laws/show/994_667.

14. Constitution of Ukraine. The Law of Ukraine of 28.06.1996 No. 254k/96-VR. [Electronic resource]. - Access mode: http://zakon3.rada. gov.ua/laws/show/254\%D0\%BA/96-\%D0\%B2\%D1\%80. (in Ukrainian)

15. Petryshyna M.O., Petryshyn O.O. International legal standards in the field of local self-government. Kh.: Pravo, 2016. 44 p. (in Ukrainian)

16. On Local Self-Government in Ukraine. The Law of Ukraine dated May 21, 1997 No. 280/97. [Electronic resource]. - Access mode: http://zakon3.rada.gov.ua/laws/show/280/97-\%D0\%B2\%D1\%80. (in Ukrainian)

17. On Service in Local Self-Government Bodies. The Law of Ukraine dated June 07, 2001 No. 2493-III. [Electronic resource]. - Access mode: http://zakon5.rada.gov.ua/laws/show/2493-14. (in Ukrainian)

18. On Public Self-Organization Bodies. The Law of Ukraine dated July 11, 2001 No. 2625-III. [Electronic resource]. - Access mode: http://zakon2.rada.gov.ua/laws/show/2625-14. (in Ukrainian)

19. On Cooperation of Territorial Communities. The Law of Ukraine dated June 17, 2014 No. 1508-VII. [Electronic resource]. - Access mode: http://zakon3.rada.gov.ua/laws/show/1508-18. (in Ukrainian)

20. On Principles of State Regional Policy. The Law of Ukraine dated February 05, 2015 No. 156-VIII. [Electronic resource]. - Access mode: http://zakon3.rada.gov.ua/laws/show/156-19. (in Ukrainian)

21. On Local Elections. The Law of Ukraine dated July 14, 2015 No. 595-VIII. [Electronic resource]. - Access mode: http://zakon5.rada.gov.ua/laws/show/595-19. (in Ukrainian)

22. On Amendments and Declaring Lapsed Some Legislative Acts of Ukraine. The Law of Ukraine dated December 28, 2014 No. 76-VIII. [Electronic resource]. - Access mode: http://zakon2.rada.gov.ua/ laws/show/76-19/paran130\#n130. (in Ukrainian)

23. On Amendments to Some Legislative Acts of Ukraine on Extending the Authorities of Local Self-Government Bodies and Optimizing the Provision of Administrative Services. The Law of Ukraine dated December 10, 2015 No. 888-VIII. [Electronic resource]. - Access mode: http://zakon2.rada.gov.ua/laws/show/888-19/paran44\#n44. (in Ukrainian)

24. On Amendments to Some Legislative Acts of Ukraine on the Implementation of the Automated System of Accounting for Fare Payment in Urban Passenger Transport. The Law of Ukraine dated January 17, 2017 
No. 1812-VIII. [Electronic resource]. - Access mode: http://zakon2.rada.gov.ua/laws/show/1812-19/paran39\#n39. (in Ukrainian)

25. On election of deputies of the Verkhovna Rada of the Autonomous Republic of Crimea, local councils and village, settlement, city mayors. The Law of Ukraine dated July 10, 2010 No 2487-VI. [Electronic resource]. - Access mode: http://zakon3.rada.gov.ua/laws/show/2487-17. (in Ukrainian)

26. Martseliak O.V. Electoral system in Ukraine: search for the optimal model // Bulletin of the Kharkiv National University of Internal Affairs. 2007. - No. 37. - P. 73-84. (in Ukrainian)

27. Tolkovanov V.V. Priorities and approaches to modernization of local self-government at the present stage: domestic and foreign experience // The theory and practice of public administration and local self-government. - 2017. - No. 1. [Electronic resource]. - Access mode: http://el-zbirn-du.at.ua/2017_1/28.pdf. (in Ukrainian)

28. Belukha L.A. The concept of territorial community and capable territorial community / Theory and practice of public administration. 2017. - No. 1(56). [Electronic resource]. - Access mode: http://www.kbuapa.kharkov.ua/e-book/tpdu/2017-1/doc/3/02.pdf. (in Ukrainian)

29. Stop the practice of finding reasons and take legal opportunities Minregion to the CEC: Decentralization. - 2017. - [Electronic resource]. Access mode: http://decentralization.gov.ua/news/7380. (in Ukrainian)

30. First Elections in United Communities. An Analytical Report. Committee of Voters of Ukraine. Kyiv. - 2017. - 45 p. (in Ukrainian)

31.Decentralization - 2017. The reform will go on. - 2017. [Electronic resource]. - Access mode: https://sorada.gov.ua/actual/18489detsentralizatsija-2017-reforma-bude-prodovzhuvatys.html. (in Ukrainian)

32. On Amendments to Some Legislative Acts of Ukraine (on Voluntary Association of Territorial Communities). The Law of Ukraine dated June 03, 2016. No. 4772. [Electronic resource]. - Access mode: http://w1.c1.rada.gov.ua/pls/zweb2/webproc4_1?pf3511=59314.

Ukrainian)

33. On Amendments to Some Legislative Acts of Ukraine on the Features of Voluntary Association of Territorial Communities Located in the Territories of Adjacent Areas. The Law of Ukraine dated December 09, 2016 No. 5520. [Electronic resource]. - Access mode: http://w1.c1.rada.gov.ua/pls/zweb2/webproc4_1?pf3511=60681.

(in Ukrainian) 
34. On Amendments to the Law of Ukraine "On Voluntary Association of Territorial Communities" on the voluntary accession of territorial communities of villages, settlements to territorial communities of cities of regional significance. The Law of Ukraine dated April 03, 2018 No. 2379-VIII. [Electronic resource]. - Access mode: http://w1.c1.rada.gov.ua/pls/ zweb2/webproc4_1?pf3511=61814. (in Ukrainian)

35. Opinion of the Head Scientific and Expert Office on the Draft Law «On Amendments to the Law of Ukraine "On Voluntary Association of Territorial Communities" on the voluntary accession of territorial communities of villages, settlements to territorial communities of cities of regional significance» dated June 06, 2017. [Electronic resource]. - Access mode: http://w1.c1.rada.gov.ua/pls/zweb2/webproc4_1?pf3511=61814. (in Ukrainian)

\section{Information about the author:}

Panchyshyn R. I.,

Candidate of Juridical Science, Postdoctoral Student at the Department of Constitutional Law and Comparative Law, Uzhgorod National University 3, Narodna Sq., Uzhhorod, 88000, Ukraine 